\title{
Morpho-anatomy and ontogeny of the underground system of Chrysolaena simplex (Less.) Dematt. (Asteraceae)
}

\author{
VANESSA S. SANTOS ${ }^{1}$, VINICIUS P. SOUZA ${ }^{1}$, DIVINA A.A. VILHALVA ${ }^{2}$, FERNANDA \\ P.S. FERREIRA ${ }^{2}$, JOSÉ R. PAULA ${ }^{3}$ and MARIA HELENA REZENDE ${ }^{2}$ \\ ${ }^{1}$ Programa de Pós-Graduação em Biodiversidade Vegetal, Instituto de Ciências Biológicas, Universidade \\ Federal de Goiás, Campus Samambaia, Av. Esperança, s/n, 74690-900 Goiânia, GO, Brasil \\ ${ }^{2}$ Departamento de Botânica, Instituto de Ciências Biológicas, Universidade Federal de Goiás, \\ Campus Samambaia, Av. Esperança, s/n, 74690-900 Goiânia, GO, Brasil \\ ${ }^{3}$ Laboratório de Pesquisa em Produtos Naturais, Faculdade de Farmácia, Universidade Federal de Goiás, \\ Rua 240, Esquina com 5ª Avenida, s/n, Setor Leste Universitário, 74605-170 Goiânia, GO, Brasil
}

Manuscript received on December 10, 2014; accepted for publication on May 24, 2015

\begin{abstract}
The occurrence of thickened underground systems in Asteraceae is widely reported in the literature. Given the great complexity of underground systems, which may originate from roots, stems, or both, morphoanatomical analyses are essential to ensure the use of correct terminology. The goals of this study were to describe the morpho-anatomy and ontogeny, investigate the occurrence of secondary metabolites and evaluate the effects of seasonality on the underground system of Chrysolaena simplex (Less.) Dematt. Samples were studied using standard protocols of plant anatomy, scanning electron microscopy, histochemical and phytochemical. The underground system of $C$. simplex was categorised as a rhizophore which started from cotyledonary node. In adult individuals, with rhizophores completely developed, the primary roots degenerated and adventitious radicular systems are formed. The buds in the subterranean portions promote the rhizophore growing, and form aerial stems when exposed to light. Lipophilic droplets were evident in the parenchymatous cells of the cortex and pith, endodermis and buds. Inulin-type fructans were observed in the stem axis and buds of the rhizophore. The presence of buds, secondary metabolites and the storage of fructans and lipids in the rhizophore can be seen as adaptive traits.
\end{abstract}

Key words: bud, cerrado, fructan, phytochemical, rhizophore, secretory ducts.

\section{INTRODUCTION}

Theaerial parts ofmany cerradoplant species dieback during the dry season and only the underground system persists. After the environmental conditions become favourable, these species resprout from these subterranean structures (Filgueiras 2002).

Correspondence to: Maria Helena Rezende

E-mail: mhrezende@uol.com.br
A variety of thickened underground systems are frequently observed in plants from cerrado, caatinga, and rupestrian environments, suggesting a remarkable adaptation to the environment's adverse conditions (Menezes et al. 1979, Paviani and Haridasan 1988). In addition, these underground systems can also play an important role in vegetative propagation of some species (Rizzini and Heringer 1962, 1966, Filgueiras 2002). 
Neither organographic nor anatomic aspects of these underground systems have received much attention from researchers (Andreata and Menezes 1999). Despite a profusion of technical terms, they often seem insufficient to describe a given subterranean structure (Milanez and Moraes-Dallaqua 2003). Underground systems may originate from roots, stems, or both. As a consequence, observations based exclusively on external morphology are insufficient to characterize their structure, which can only be appropriately studied with anatomical analyses (Vilhalva and Appezzato-da-Glória 2006a).

The occurrence of thickened underground systems in Asteraceae is widely reported in the literature, including xylopodia, rhizophores, tuberous roots, diffuse underground systems and rhizomes (Paviani 1977, 1978, 1987, Menezes et al. 1979, Sajo and Menezes 1986, Lotocka and Geszprych 2004, Machado et al. 2004, Hayashi and Appezzato-da-Glória 2005, 2007, Vilhalva and Appezzato-da-Glória 2006a, b, Appezzatoda-Glória et al. 2008a, b, Cury and Appezzato-daGlória 2009, Appezzato-da-Glória and Cury 2011, Vilhalva et al. 2011, Bombo et al. 2014). Many Asteraceae species have fructans in the thickened underground systems (Tertuliano and FigueiredoRibeiro 1993). Fructans are undoubtedly storage compounds in perennial herbs of cerrado (Figueiredo-Ribeiro 1993).

Given the ecological importance of underground systems (White et al. 2013), the present study aimed to characterise the morpho-anatomy, ontogeny and histochemistry of Chrysolaena simplex, a species in Asteraceae, which is frequent in the study's area, showed a peculiar thickened underground system without previous studies in the literature. In addition, we investigated the presence of certain classes of secondary metabolites through phytochemical analyses of this system.

\section{MATERIALS AND METHODS}

The collection area is a rupestrian environment in the Biological Reserve "Prof. José Ângelo Rizzo" of Universidade Federal de Goiás (UFG), Brazil, located in the Parque Estadual da Serra Dourada (PESD), in the municipalities of Mossâmedes, Goiás and Buritis de Goiás. Elevation ranged from $726 \mathrm{~m}$ to $900 \mathrm{~m}$, and geographic coordinates were within $16^{\circ} 06^{\prime} 02^{\prime \prime}$ and $16^{\circ} 03^{\prime} 52^{\prime \prime} \mathrm{S}$ and $50^{\circ} 10^{\prime} 59^{\prime \prime}$ and $50^{\circ} 10^{\prime} 12^{\prime \prime}$ W. Chrysolaena simplex was collected from areas of "campo rupestre" (around the point of coordinates $16^{\circ} 04^{\prime} 11^{\prime \prime} \mathrm{S}$ and $50^{\circ} 10^{\prime} 48^{\prime \prime}$ $\mathrm{W})$, which is one of the phytophysiognomies present in the so called rupestrian environment. "Campo rupestre" is a grassland with rocky soil and/or gravel soil, a variety of herbaceous plants, few bushes, and trees sparse or absent.

We collected the underground systems of three adult individuals of Chrysolaena simplex, per season. The samples were processed in the Laboratório de Anatomia Vegetal do Departamento de Botânica/Instituto de Ciências Biológicas/UFG for morphological, anatomical and histochemical analyses. In addition, other ten adult individuals were collected per season, for phytochemical analyses carried out in the Laboratório de Pesquisa em Produtos Naturais, Faculdade de Farmácia/ UFG. Collections were carried out in the dry (May to October) and rainy (November to April) seasons. A specialist identified the plant material, and a voucher specimen was deposited at the herbarium of Universidade Federal de Goiás, Brazil (C. simplex 47930 UFG). The morphology was described based on field observations at the time of collection and photographic records, supplemented by analyses and descriptions made in the lab with the aid of a stereomicroscope.

For anatomical analyses, whole underground systems were fixed in FAA-50 (Johansen 1940) and vacuum-treated to remove air from plant tissues. The plant material was sectioned as shown in Fig. 
1c. Part of the samples was dehydrated through an ethyl alcohol series and infiltrated with plastic resin (Leica Historesin). Longitudinal and cross sections (10 to $12 \mu \mathrm{m}$ thick) were obtained using a Spencer rotary microtome with disposable blades (Leica model 818) and a Leica RM2245 microtome with disposable tungsten carbide blades TC-65. Sections were stained with toluidine blue in Mcllvaine buffer $\mathrm{pH} 4.0$ (Vidal 1977) and dehydrated through an ethyl alcohol series. Permanent slides were mounted in Entellan resin.

Sections cut free-hand and with a table microtome were cleared for approximately one minute in $6 \%$ sodium hypochlorite, rinsed in distilled water, and double stained with $0.1 \%$ aqueous basic fuchsin and $0.3 \%$ astra blue (Roeser 1972, Kraus et al. 1998). Sections were mounted in $50 \%$ glycerine.

Free-hand sections of non-fixed, recently collected material were used to detect certain classes of metabolites. These sections were treated with Sudan IV to detect lipophilic substances (Gerlach 1984); ferric chloride for phenolic compounds (Johansen 1940); Lugol's solution for starch (Johansen 1940); Steinmetz, also known as a universal reagent, to detect starch, cellulose, lignin and miscellaneous lipids simultaneously (Costa 1970); and periodic acid-Schiff's reagent (PAS) for neutral polysaccharides (Maia 1979). Crosssections were dehydrated in $100 \%$ ethanol for 48 hours (Purvis et al. 1964) to visualize crystals of inulin under polarised light.

Photomicrographs were taken using a Leica microscope, a ICC50 digital camera, image capture software LAD EZ version 1.8.1, and a stereo microscope with a digital Leica EZ4D camera, using LAD EZ version 1.8.0.

Samples to be analysed by scanning electron microscopy (SEM) were cross-sectioned and fixed in a modified Karnovsky's solution (Karnovsky 1965 ) with cacodylate buffer, dehydrated through an ethyl alcohol series, critical-point dried using
$\mathrm{CO}_{2}$, mounted on stubs, and coated with gold. The material was analysed using a JEOL JSM6610 scanning electron microscope (JEOL) with an energy dispersive system (EDS) (Thermo Scientific NSS spectral imaging), at the Laboratório Multiusuário de Microscopia de Alta Resolução LABMIC.

Qualitative tests for phytochemical screening were based on the methods described by Matos (1994) and Costa (2001). We investigated the presence of the following classes of natural chemical compounds: anthraquinone heterosides, digitalic heterosides, steroids and triterpenoids, flavonoid heterosides, tannins, alkaloids, saponinic heterosides and coumarins. Samples collected in the dry and rainy seasons were triple-analysed to determine flavonoid content, using the method described by Rolim et al. (2005).

Specifically for the ontogeny analysis of the underground system of $C$. simplex, cipselas were sowed in pots containing the soil from the same site where adult plants were collected. After germination, once a week a seedling was collected to observe if there were morphological changes in the subterranean system. For each of these development stages, three individuals were collected and fixed in FAA-50 for 48 hours. For anatomical analyses, samples was dehydrated through an ethyl alcohol series and infiltrated with plastic resin (Leica Historesin). Cross sections (10 to $12 \mu \mathrm{m}$ thick) were obtained using a Spencer rotary microtome with disposable blades (Leica model 818) and a Leica RM2245 microtome with disposable tungsten carbide blades TC-65. Sections were stained with toluidine blue in Mcllvaine buffer pH 4.0 (Vidal 1977) and dehydrated through an ethyl alcohol series. Permanent slides were mounted in Entellan resin.

\section{RESULTS}

The studied individuals of $C$. simplex were herbaceous (Fig. 1a) whose underground systems 
were rhizophores (Fig. 1b-d), characterized by a stem-based structure, positive geotropism, buds covered by cataphylls, and numerous adventitious roots. The rhizophores were located near the soil's surface, $c a .10 \mathrm{~cm}$ deep, and generated aerial stems that formed clumps (Fig. 1b). In adult individuals, there were many buds in the rhizophore in close proximity and covered by cataphylls, and adventitious roots originated from the entire organ (Fig. 1c-d). Adventitious roots were more abundant during the rainy season (Fig. 1c), while buds were more common during the dry season (Fig. 1d).

The origin of the rhizophores was revealed by the ontogenetic study of individuals obtained by germination of cypselae (Fig. 2a). Different developmental stages of the rhizophore are illustrated in Fig. 2b-g. Initially, the radicle emerged, followed by elongation of the hypocotyl (Fig. 2b). The formation of the rhizophore started approximately two months after germination (Fig. $2 \mathrm{c}-\mathrm{d})$, from cotyledonary node. There were usually two rhizophores, one in the axil of each cotyledon (Fig. 2c-e). The formation of the rhizophore and its positive geotropism is shown in Fig. 2c, e-f. In adult individuals, with rhizophores completely formed, primary roots degenerated to an adventitious radicular system (Fig. 2g). The buds in the subterranean portions promote the rhizophore growing, and formed aerial stems when exposed to light.
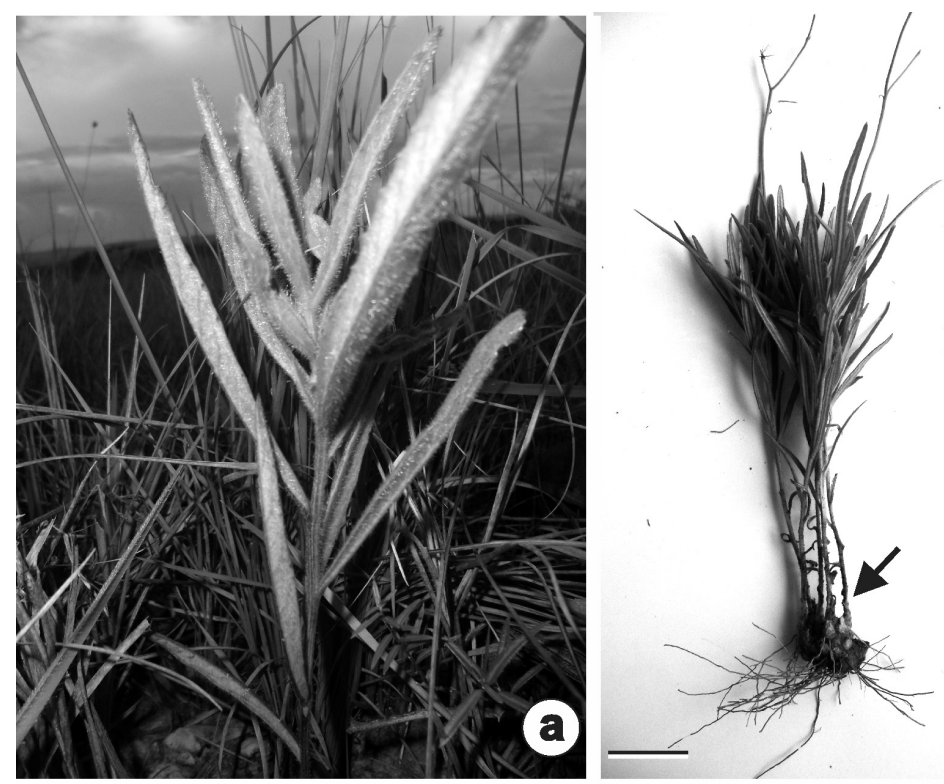

(b)
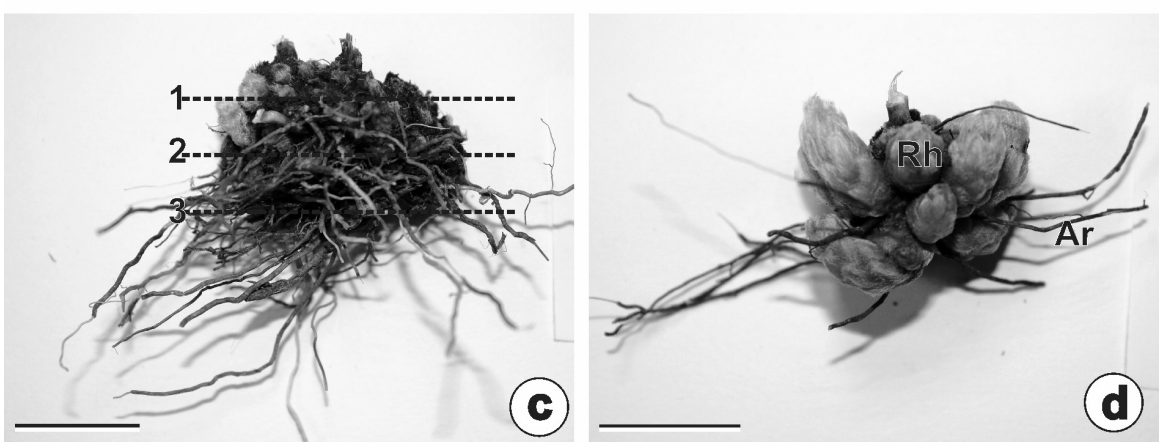

Figure 1 - Chrysolaena simplex. (a) Adult individual. (b) Rhizophore sending many aerial stems. (c) Rhizophore in the rainy season. (d) Rhizophore in the dry season. 1 - 3: section planes studied anatomically; arrow: aerial stems; Ar: adventitious root; Rh: rhizophore. Scale bars, $5 \mathrm{~cm} \mathrm{(b);} 2 \mathrm{~cm}(\mathbf{c}, \mathbf{d})$. See the colors in the online version. 

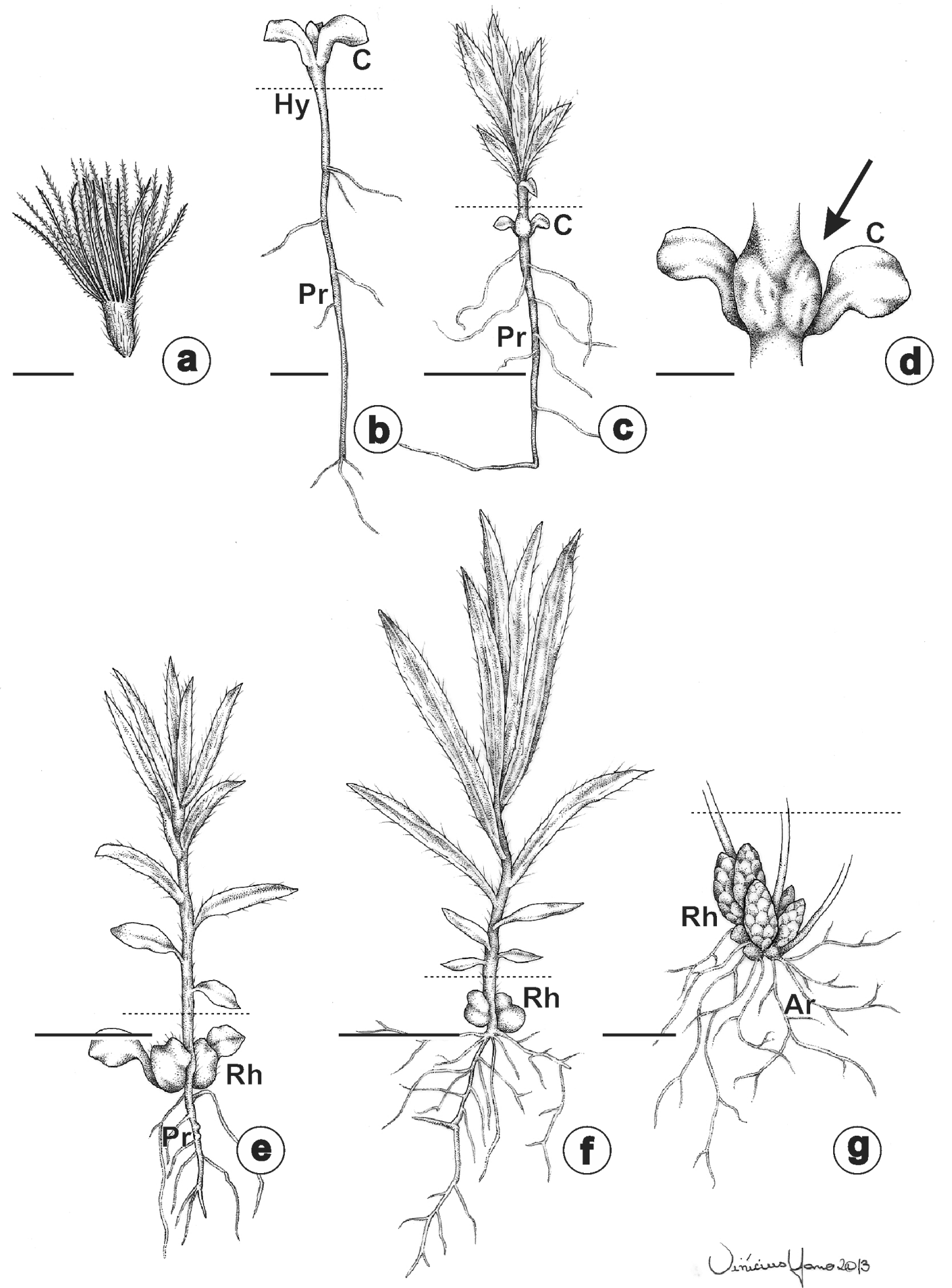

Figure 2 - Developmental stages of Chrysolaena simplex. (a) General view of the cypsela. (b) Fifteen-day-old individual. (c, d) Two-and-a-half-month-old individual. (c) General view. (d) Cotyledonary node; arrow points to rhizophore formation. (e) Three-month-old individual. (f) Four-month-old individual. (g) Adult individual. Ar: adventitious roots; C: cotyledons; Hy: hypocotyl; Pr: Primary root; Rh: rhizophore; Dashed line: Soil level. Scale bars, $2.5 \mathrm{~mm}$ (a); $3 \mathrm{~mm}$ (b); $9 \mathrm{~mm}$ (c); $1 \mathrm{~mm}$ (d); $1.5 \mathrm{~cm}$ (e, g); $2.5 \mathrm{~cm}$ (f). See the colors in the online version. 
The stem origin of the rhizophore could be observed in serial cross-sections made on planes 1, 2 and 3 (Fig. 3a). The upper part of the early developing rhizophore (Fig. 3a, plane 1) had a vascular system comprised of six collateral bundles (Fig. 3b). In the central part (Fig. 3a, plane 2) we observed buds, opposite the lateral bundles (Fig. 3c-d). Lateral expansion of the rhizophore occurred in the lower part (Fig. 3a, plane 3), as seen in Fig. $3 \mathrm{e}$. Figure $3 \mathrm{f}$ shows the anatomical structure of the hypocotyl, from a cross-section at Plane 4 of Fig. 3a.

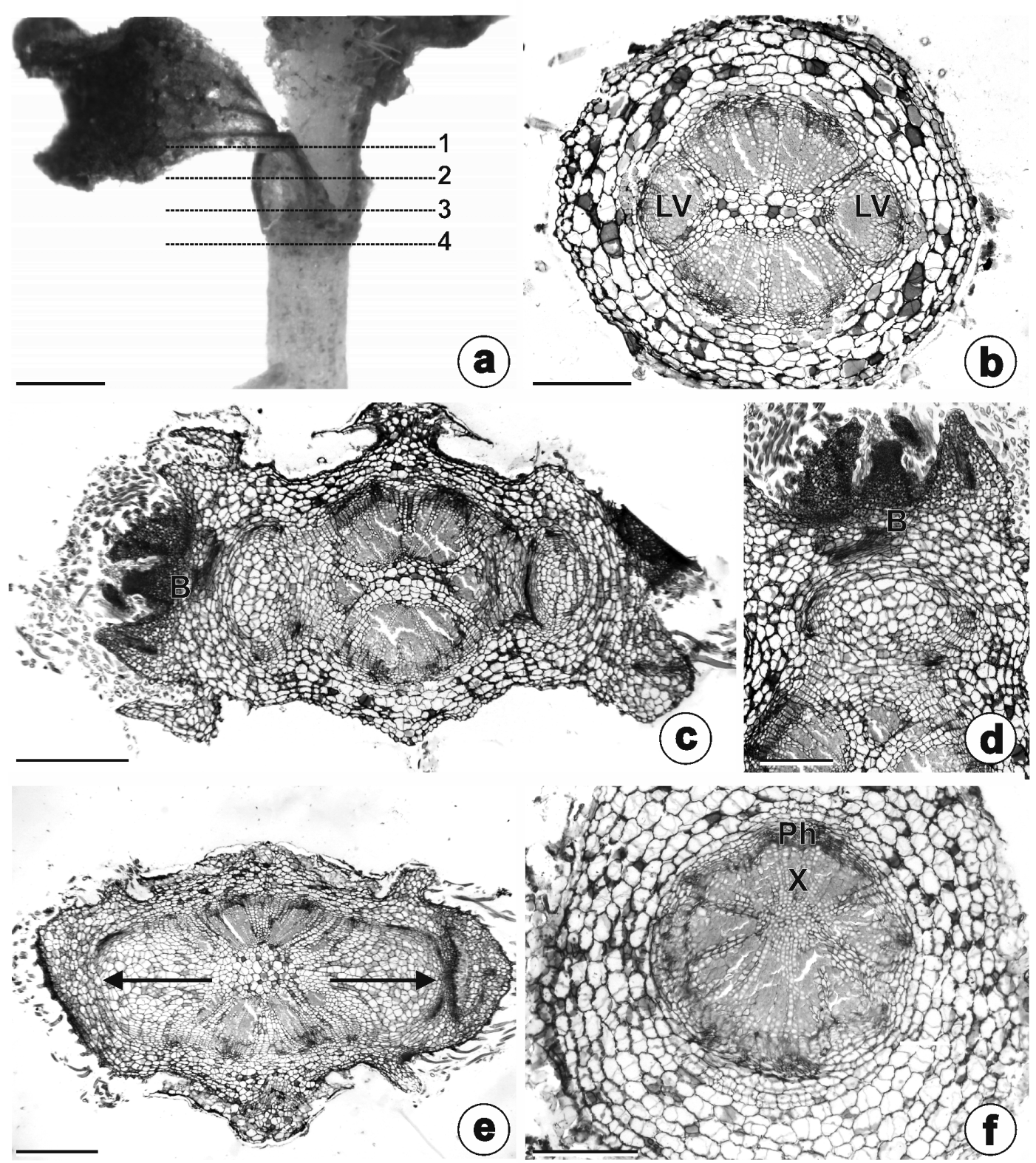

Figure 3 - Initial rhizophore development in a two-and-a-half-month-old Chrysolaena simplex. (a) Individual. (b-e) Cross-sections of the rhizophore. (b) Upper part with six collateral bundles. (c-d) Central part. (c) General view showing buds. (d) Detail of the bud. (e) Lower part showing lateral elongation (arrows). (f) Cross-sections of the hypocotyl. B: bud; LV: lateral vascular bundles; Ph: primary phloem; X: primary xylem. Section planes analysed: 1: upper part of the rhizophore; 2: central part; 3: lower part; 4: hypocotyl. Scale bars, $2 \mathrm{~mm}$ (a); 500 $\mu \mathrm{m}(\mathbf{b}, \mathbf{d}, \mathbf{f}) ; 1000 \mu \mathrm{m}$ (c, e). See the colors in the online version. 
The rhizophores of adult individuals had self-grafting stem axes (Fig. 4a). The general appearance of the anatomical structure and a wide parenchymatous pith is illustrated by Fig. $4 \mathrm{~b}$. The primary structure of the rhizophores were covered by an unistratified epidermis with stomata and non-glandular trichomes (Fig. 4c, e). The cortical region were composed by parenchymatous cells and showed endodermis with Casparian strips (Fig. 4c-d); the vascular system was comprised of collateral bundles with eustele arrangement and a parenchymatous medullary region (Fig. 4c). There were lipophilic droplets in the parenchymatous cells of the cortex, endodermis, all of the paren- chymatous pith (Fig. 4e), and buds. Starch and phenolic compounds were not detected.

The buds and cataphylls of the rhizophores of adult individuals had inulin-type fructans, which were observed as spherocrystals under polarized light (Fig. 5a), using the PAS method (Fig. 5b) and SEM (Fig. 5c-d). Inulin crystals were larger during the dry season, completely filling the cellular lumen (Fig. 5c). In contrast, in the rainy season these crystals were smaller and placed on cellular walls (Fig. 5d).

The adventitious roots had unistratified epidermis, exodermis, a cortical region composed by parenchymatous cells with thin walls and by
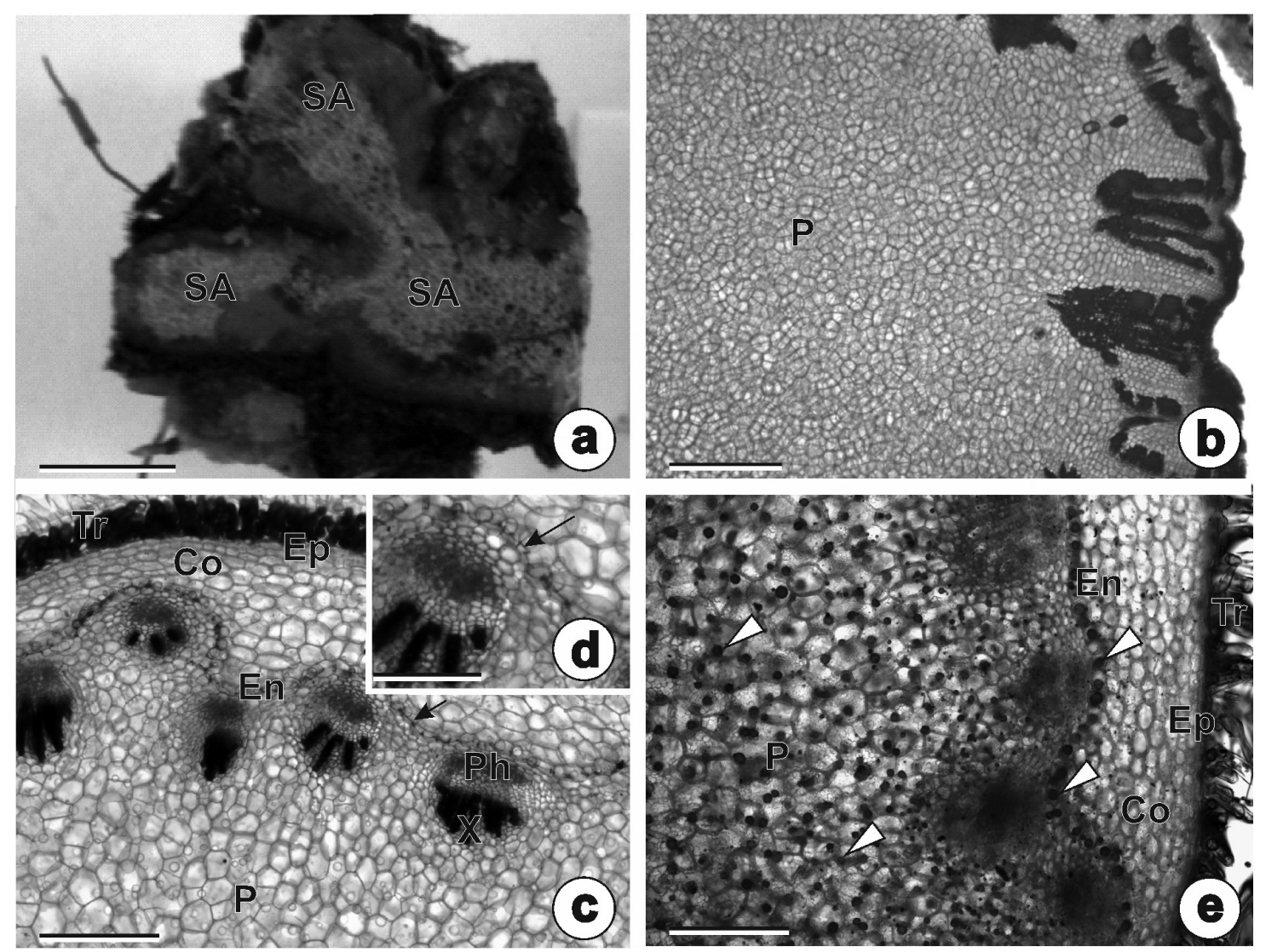

Figure 4 - Cross-sections of the rhizophore of adult Chrysolaena simplex. (a) Frontal view of the proximal region of the rhizophore with three interconnected stem axes. (b) Proximal region - general view showing the wide parenchymatous pith. (c) Detail of the vascular bundles and endodermis with Casparian strips (arrow). (d) Casparian strips (arrow). (e) Lipophilic droplets stained by Sudan III (arrows). Co: cortex; Ep: epidermis; En: endodermis; P: pith; Ph: phloem; SA: stem axes; Tr: non-glandular trichome; X: primary xylem. Scale bars, $1 \mathrm{~cm}$ (a); $0.05 \mathrm{~cm}$ (b); $500 \mu \mathrm{m}$ (c, e); $250 \mu \mathrm{m}$ (d). See the colors in the online version. 
cells with thickened, lignified walls (Fig. 5e). Secretory ducts with a rhomboid lumen arranged into one or two layers were observed opposite the phloem (Fig. 5e-f). The vascular cylinder was polyarch, and the pith was completely sclerified
(Fig. 5e). Figure $5 \mathrm{~g}$ shows a longitudinal section of the secretory duct, with some lipophilic droplets.

The main classes of secondary metabolites identified by the phytochemical screening of rhizophore fragments (stem axis and adventitious
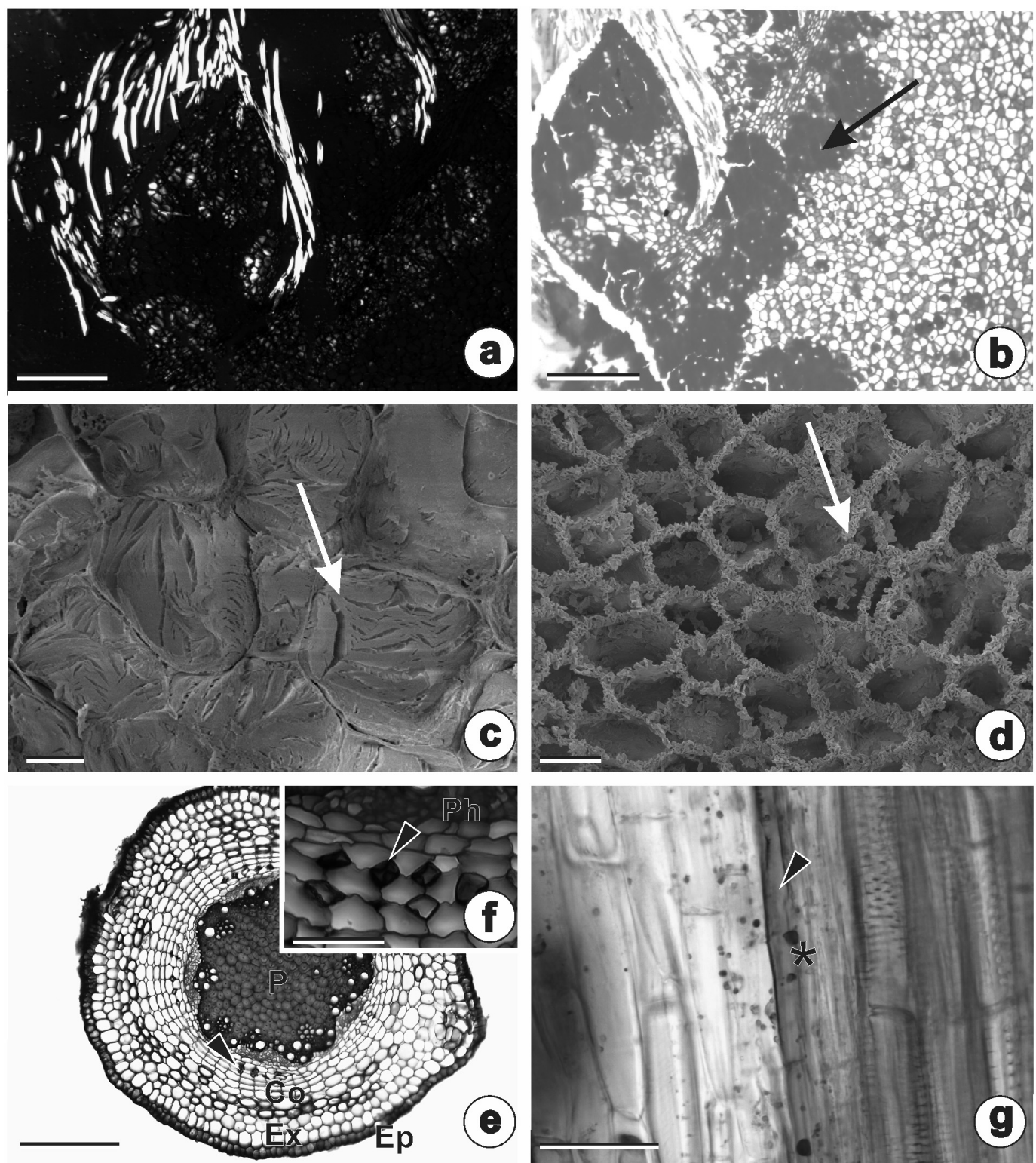

Figure 5 - Chrysolaena simplex. (a-b). Longitudinal sections of the rhizophore. (a) Bud in polarized light with inulin spherocrystals. (b) Cataphyll region with positive reaction to PAS (arrow). (c) Dry-season bud with inulin crystals filling all of the cellular lumen (arrow). (d) Dry-season bud with crystals placed to the cellular walls (arrow). (e-g) Adventitious roots (e) General view showing secretory ducts with rhomboid lumen opposite phloem (arrowhead). (f) Detail of the secretory ducts (arrowhead). (g) Longitudinal section showing secretory ducts (arrowhead) with lipophilic substances $\left({ }^{*}\right)$ - Steinmetz. Co: cortex; Ep: epidermis; Ex: exodermis; P: pith; Ph: phloem. Scale bars, $1000 \mu \mathrm{m}$ (a); $500 \mu \mathrm{m}$ (b); $10 \mu \mathrm{m}$ (c); $20 \mu \mathrm{m}$ (d); $500 \mu \mathrm{m}$ (e); 100 $\mu \mathrm{m}$ (f, $\mathbf{g})$. See the colors in the online version. 
roots) are presented on Table I. Samples of $C$. simplex had saponins with a foaming index of 111.1. The levels of total flavonoids in the rhizophore samples from dry and rainy season were $0.68 \%$ and $1.12 \%$, respectively.

TABLE I

Main classes of secondary metabolites found in rhizophore samples of Chrysolaena simplex.

\begin{tabular}{lc}
\hline Secondary metabolite class & Result \\
\hline Anthraquinone Heterosides & - \\
Digitalic Heterosides & - \\
Steroids and Triterpenoids & + \\
Flavonoid Heterosides & + \\
Tannins & - \\
Alkaloids & - \\
Saponinic Heterosides & + \\
Coumarins & + \\
\hline
\end{tabular}

Positive reaction: +; Negative reaction: -.

\section{DISCUSSION}

The underground system of Chrysolaena simplex was a rhizophore. This term was used for the first time in Asteraceae by Menezes et al. (1979) to refer to a new and peculiar type of subterranean stem system in species of Vernonia from campos rupestres in Serra do Cipó. These authors have proposed the term rhizophore in analogy to the organ with roots present in Selaginella.

In Brazil, after the precursor work by Menezes et al. (1979), rhizophores were also described for other species in Asteraceae (Sajo and Menezes 1986, Melo-de-Pinna and Menezes 2002, Machado et al. 2004, Hayashi and Appezzato-da-Glória 2005, Appezzato-da-Gloria et al. 2012), Dioscoreaceae (Rocha and Menezes 1997), Smilacaceae (Andreatta and Menezes 1999, Martins and Appezzato-daGlória 2006) and Rhizophoraceae (Menezes 2006).

The anatomical analysis of the underground system of $C$. simplex confirmed a stem-based organ. Numerous buds protected by cataphylls and thin adventitious roots were observed, mirroring the rhizophores described by Menezes et al. (1979),
Sajo and Menezes (1986), Melo-de-Pinna and Menezes (2002), Machado et al. (2004) and Hayashi and Appezzato-da-Glória (2005). In addition, the ontogenetic study revealed that the development of the rhizophore of $C$. simplex is similar to those in Vernonia psilophylla, $V$. linearifolia, $V$. sessilifolia (Sajo and Menezes 1986), $V$. herbaceae and $V$. platensis (Hayashi and Appezzato-da-Glória 2005).

The rhizophore in $C$. simplex had a great amount of lipophilic substances stored in the parenchymatous cortex, endodermis and pith, much the same as the rhizophores of Vernonia herbacea and V. platensis (Hayashi and Appezzatoda-Glória 2005). In addition, there were stomata on the surface of the rhizophore, which Andreata and Menezes (1999) interpreted as an indication that these organs were derived from aerial structures, similarly to what occurs in pteridophytes.

Fructans were smaller in the rainy season, when the plants initiated resprouting. The possibility of quickly metabolising and using fructans as soon as there is an increase in water availability may represent an advantage for plants that accumulate these polysaccharides and are adapted to survive under temporarily dry conditions (FigueiredoRibeiro 1993). Vilhalva and Appezzato-da-Glória (2006b) and Bombo et al. (2014) emphasise that the storage of two kinds of reserves, lipids and fructans, are clear adaptations to the adverse conditions in the cerrado. In addition, the number of adventitious roots on the rhizophore of $C$. simplex was greater in the rainy season. Menezes (2007) notes that adventitious roots derived from rhizophores absorb all the water and nutrients in plants with these underground systems.

The secretory ducts opposite the phloem, which contained the lipophilic substances found in the adventitious roots of $C$. simplex, were similar to those in Chromolaena squalida, Gyptis lanigera, Pterocaulon angustifolium, Chresta sphaerocephala, Lessingianthus bardanoides, L. glabratus and Orthopappus angustifolius, studied 
by Appezzato-da-Glória et al. (2008b). According to these authors, ducts located opposite the phloem are a defence against herbivores. Their location differs from ducts of Smallanthus sonchifolius, which are found along the perimeter of the endodermis (Machado et al. 2004).

The flavonoid content increased from dry season to rainy season. Phytochemical screening studies in underground systems are scarce and the relationship between seasonality and the flavonoid content is reported only in studies of aerial organs.

Based on structure and anatomical analyses, the underground system of $C$. simplex can be classified as a rhizophore. The presence of buds and the storage of fructans and lipids in the rhizophore are putative adaptive traits that allow vegetative propagation and plant survival following adverse events common in the cerrado, such as prolonged droughts and fire. The studied species had many secondary metabolites (flavonoids, saponins, coumarins, steroids and triterpenoids), which may indicate adaptation and/or tolerance to the rupestrian environment. Fructans were seasonal, and were larger during the dry season, when they completely filled the cellular lumen, and smaller in the rainy season, when they remained attached to the cellular wall.

\section{ACKNOWLEDGMENTS}

We thank the Coordenação de Aperfeiçoamento de Pessoal de Nível Superior (CAPES), Fundação de Amparo à Pesquisa do Estado de Goiás (FAPEG) for the Masters scholarships provided to the first and second authors, respectively and Dr. Aristônio Magalhães Teles, who has identified the plant material.

\section{RESUMO}

A presença de sistemas subterrâneos espessados em Asteraceae tem sido amplamente relatada na literatura. Devido à grande complexidade dos sistemas subterrâneos, que podem ser de natureza radicular, caulinar ou mista, as análises morfoanatômicas são importantes para assegurar a utilização da terminologia correta. Este estudo teve por objetivo descrever a morfoanatomia e ontogenia, investigar a presença de metabólitos secundários e avaliar os efeitos da sazonalidade no sistema subterrâneo de Chrysolaena simplex (Less.) Dematt. As amostras foram estudadas usando os protocolos padrão de anatomia vegetal, eletrônica de varredura, histoquímica e fitoquímica. O sistema subterrâneo de $C$. simplex foi identificado como rizóforo, que se originou do nó cotiledonar. Em indivíduos adultos, com rizóforos completamente desenvolvidos, as raízes primárias degeneram e formam sistemas radiculares adventícios. As gemas, nas porções subterrâneas, promovem o crescimento do rizóforo e formaram caules aéreos quando expostas à luz. Gotas lipofílicas foram evidenciadas nas células parenquimáticas do córtex e medula, endoderme e gemas. Frutanos tipo inulina foram evidenciados no eixo caulinar e gemas do rizóforo. A ocorrência de gemas, metabólitos secundários, frutanos e lipídeos armazenados no rizóforo, podem ser apontados como caracteres adaptativos.

Palavras-chave: gemas, cerrado, frutanos, fitoquímica, rizóforos, ductos secretores.

\section{REFERENCES}

ANDREATA RH AND MENEZES NL. 1999. Morfoanatomia do embrião, desenvolvimento pós-seminal e origem do rizóforo de Smilax quinquenervia Vell. (Smilacaceae). Bol Bot 18: 39-51.

APPEZZATO-DA-GLÓRIA B, Costa FB, SILVA VC, GOBBONETO L, REHDER VLG AND HAYASHI AH. 2012. Glandular trichomes on aerial and unterground organs in Chrysolaena species (Vernonieae - Asteraceae): Structure, ultrastructure and chemical composition. Flora 207: 878887.

APPeZZATO-DA-GLÓRIA B AND CURY G. 2011. Morphoanatomical features of underground systems in six Asteraceae species from the Brazilian Cerrado. An Acad Bras Cienc 83: 981-992.

APPEZZATO-DA-GLÓRIA B, CURY G, SOARES MKM, ROCHA R AND HAYASHI AH. 2008a. Underground systems of Asteraceae species from the Brazilian Cerrado. J Torrey Bot Soc 135: 103-113.

APPEZZATO-DA-GLÓRIA B, HAYASHI AH, CURY G, SOARES MKM AND ROCHA R. 2008b. Occurrence of secretory structures in underground systems of seven Asteraceae species. Bot J Linn Soc 157: 789-796. 
BOMBO AB, OLIVEIRA TS, OLIVEIRA ASS, REHDER VLG AND APPEZZATO-DA-GLÓRIA B. 2014. Anatomy and essential oil composition of the underground systems of three species of Aldama La Llave (Asteraceae). J Torrey Bot Soc 141(2): 115-125.

CostA AF. 1970. Farmacognosia, v.3, $2^{\text {a }}$ ed., Lisboa: Fundação Calouste Gulbenkian, 1032 p.

CostA AF. 2001. Farmacognosia. v.3, $3^{\text {a }}$ ed., Lisboa: Fundação Calouste Gulbenkian, 992 p.

CURY G AND APPEZZATO-DA-GLÓRIA B. 2009. Internal secretory spaces in thickened underground systems of Asteraceae species. Aust J Bot 57: 229-239.

FIGUEIREDO-RIBEIRO RCL. 1993. Distribuição, aspectos estruturais e funcionais dos frutanos, com ênfase em plantas herbáceas do cerrado. Rev Bras Fisiol Veg 5: 203208.

FILGUEIRAS TS. 2002. Herbaceous plant communities. In: Oliveira PS and Marquis RJ (Eds), The cerrados of Brazil: ecology and natural history of a Neotropical savanna, New York: Columbia University Press, p. 121-139.

GERLACH D. 1984. Botanische mikrotechnik, Stuttgart: Georg ThiemeVerlag, $311 \mathrm{p}$.

HAYASHI AH AND APPEZZATO-DA-GLÓRIA B. 2005. The origin and anatomy of rhizophore in Vernonia herbacea and $V$. platensis (Asteraceae) from the Brazilian Cerrado. Aust J Bot 53: 273-279.

JOHANSEN DA. 1940. Plant microtechnique. New York: McGraw-Hill Book Company, 523 p.

KARNOVSKY MJ. 1965. A formaldehyde-glutaraldehyde fixative of high osmolality for use in eletron microscopy. $\mathrm{J}$ Cell Biol 27: 137-138.

Kraus JE, SOUZA HC, REZENDE MH, CASTRo NM, VECCHI C AND LUQUE R. 1998. Astra blue and basic fuchsin double staining methods for plant materials. Biotech Histochem 73: 235-243.

LotockA B AND GESZPRYCH A. 2004. Anatomy of the vegetative organs and secretory structures of Rhaponticum carthamoides (Asteraceae). Bot J Linn Soc 144: 207-233.

MACHAdO SR, OLIVEIRA DMT, DIP MR AND MENEZES NL. 2004. Morfoanatomia do sistema subterrâneo de Smallanthus sonchifolius (Poepp. and Endl.) H. Robinson (Asteraceae). Rev Bras Bot 27: 115-123.

MAIA V. 1979. Técnica histológica. 2a ed., São Paulo: Atheneu Editora, p. 70-136.

MARTINS AR AND APPEZZATO-DA-GLÓRIA B. 2006. Morfoanatomia de órgãos vegetativos de Smilax polyantha Griseb. (Smilacaceae). Rev Bras Bot 29: 555-567.

MATOS FJA. 1994. Proposta de Validação Farmacognóstica de Drogas Vegetais, Plantas Medicinais e Fitoterápicos. Infarma 3: 1-6.

Melo-DE-PINNA GFA AND MENEZES NL. 2002. Vegetative organ anatomy of Ianthopappus corymbosus Roque \& Hind (Asteraceae-Mutisieae). Rev Bras Bot 25: 505-514.
MENEZES NL. 2006. Rhizophores in Rhizophora mangle L: an alternative interpretation of so-called "aerial roots". An Acad Bras Cienc 78: 213-226.

MENEZES NL. 2007. Rhizophore in angiosperms. An Acad Pernamb Cienc Agron 4: 340-353.

Menezes NL, Müller C AND SAJo MG. 1979. Um novo e peculiar tipo de sistema subterrâneo em espécies de Vernonia da Serra do Cipó (Minas Gerais, Brasil). Bol Bot 7: 33-38.

Milanez CRD AND MORAes-DAllaQUA MA. 2003. Ontogênese do sistema subterrâneo de Pachyrhizus ahipa (Wedd.) Parodi (Fabaceae). Rev Bras Bot 26: 415-427.

PAVIANI TI. 1977. Estudo morfológico e anatômico de Brasilia sickii G. M. Barroso. II: Anatomia da raiz, do xilopódio e do caule. Rev Bras Biol 37: 307-324.

PAVIANI TI. 1978. Anatomia vegetal e cerrado. Cienc Cult 30: 1076-1086.

PAVIANI TI. 1987. Anatomia do desenvolvimento do xilopódio de Brasilia sickii G. M. Barroso. Estágio inicial. Cienc Cult 39: 399-405.

PAVIANI TI AND HARIDASAN M. 1988. Tuberosidade em Vochysia thyrsoidea Pohl (Vochysiaceae). Cienc Cult 40: 998-1003.

PURVIS MJ, COLLIER DC AND WALLS D. 1964. Laboratory techniques in botany. London: Butterworths, $371 \mathrm{p}$.

RIZZINI CT AND HERINGER EP. 1962. Studies on the underground organs of trees and shrubs from some southern Brazilian savannas. An Acad Bras Cienc 34: 235 247.

RIZZINI CT AND HERINGER EP. 1966. Estudo sobre os sistemas subterrâneos difusos de plantas campestres. An Acad Bras Cienc 38: 85-112.

ROCHA DC AND MENEZES NL. 1997. O sistema subterrâneo de Dioscorea kunthiana Uline ex R. Knuth (Dioscoreaceae). Bol Bot Univ São Paulo 16: 1-11.

ROESER KR. 1972. Die Nadel der Schwarzkiefer-Massenprodukt ud Kunstwerk der Natur. Mikrokosmos 2: 33-36.

ROLIM A, MACIEL CPM, KANEKO TM, CONSIGLIERI VO, SALGADO-SANTOS IMN AND VELASCO MVR. 2005. Validation assay for total flavonoids, as rutin equivalents, from Trichilia catigua Adr. Juss (Meliaceae) and Ptychopetalum olacoides Bentham (Olacaceae) Commercial Extract. J AOAC Int 88: 1015-1019.

SAJO MG AND MENEZES NL. 1986. Origem e crescimento do rizóforo em espécies de Vernonia Screb. (Compositae), da Serra do Cipó, MG. Rev Bras Biol 46: 197-202.

TERTUliano MF AND FIGUEIREDO-RIBEIRO RCL. 1993. Distribution of fructose polymers in herbaceous species of Asteraceae from the cerrado. New Phytol 123: 741749.

VIDAL BC. 1977. Acid glycosaminoglycans and endochondral ossification: microspectrophotometric evaluation and macromolecular orientation. Cell Mol Biol 22: 45-64. 
VILHALVA DAA AND APPEZZATO-DA-GLÓRIA B. $2006 \mathrm{a}$. Morfoanatomia do sistema subterrâneo de Calea verticillata (Klatt) Pruski e Isostigma megapotamicum (Spreng.) Sherff. - Asteraceae. Rev Bras Bot 29: 39-47.

VILHALVA DAA AND APPEZZATO-DA-GLÓRIA B. $2006 \mathrm{~b}$. Morfoanatomia da raiz tuberosa de Vernonia oxylepis Sch. Bip. in Mart. ex Baker - Asteraceae. Acta Bot Bras 20: 591-598.
VILHALVA DAA, CORTELAZZO AL, CARVALHO MAM AND FIGUEIREDO-RIBEIRO RCL. 2011. Histochemistry and ultrastructure of Campuloclinium chlorolepis (Asteraceae) tuberous roots accumulating fructan: evidences of functions other than reserve carbohydrate. Aust J Bot 59: 46-52.

White PJ, GeOrge TS, Gregory PJ, Bengough AG, HALLETT PD AND MCKENZIE BM. 2013. Matching roots to their environment. Ann Bot 112: 207-222. 